\title{
Seminole Food: Patterns of Indigenous Foodways in South Florida, 1855 to 1917
}

\author{
Albert D. Gonzalez 1 \\ ${ }^{1}$ Department of Anthropology, Geography, and Environmental Studies \\ California State University, East Bay
}

\begin{abstract}
Few systematic historical studies of Seminole Indian foodways in Florida exist, fewer even for the critical period between Removal and World War I. This paper aims to fill the gap in related foodways and historical literature, while establishing a starting point for zooarchaeological and archaeobotanical studies on the topic. It addresses the issue from the ground up, developing an inventory of Seminole selective preferences in terms of food and tracking changes in those preferences over time. The study borrows the use of presence/absence matrices from archaeology to facilitate that analysis, treating an extensive set of related documents as a stratified matrix in which historical observations of Seminole food consumption are recorded by food type. It relies on Seminole oral histories to supplement the document index by providing additional information as to food preferences and taboos. Results of data analysis lead to the conclusion that two complimentary channels of foodways existed among Seminole Indians in South Florida at the time: (1) a conservative channel that may have maintained symbolically or nutritionally important foods, and (2) a more flexible channel that allowed for the incorporation of supplementary foods of various origins.
\end{abstract}

Keywords: Seminole, Foodways, History, Archaeology, Florida

Introduction

While the interdisciplinary body of literature on historical Eastern Woodlands and Southeastern indigenous foodways is rich and internally diverse in terms of themes and geographies (Briggs, 2015; Green, 2008; Mihesuah, 2015; Peres, 2017; VanDerwarker and Detwiler, 2002), precious few studies of historical Florida Seminole foodways exist (Weik, 2009; Sleight, 1953; Weisman, 1989). Of those, even fewer describe Seminole food consumption habits during the period between Removal and World War I in extensive, systematic, and critical detail (Bennett, 2015; Joos, 1984). This paper aims to fill the gap in that literature by analyzing documentary and oral historical evidence as to the specifics of Seminole food consumption during that time. Historical work describing
post-Removal Seminole foodways tends to provide limited details as to Seminole diet, and usually does so in service of historical illustration or in analysis of Indian roles in the pelt, plume, and hide trade (Covington, 1993, pp. 140-199; Kersey, 1975, pp. 30-126). Inferential foodways work tends to be the exception for historical study of the period rather than the rule (Frank, 2017, p. 57). Moreover, relevant archaeological work is not easily accessible, existing nearly entirely between gray literature (Fenno, 2013a, 2013b) and professional conference presentations (Lammie, 2018).

I address those issues by building from the ground up, asking the following research question: Did the corpus of locally available foods (hunted, gathered, or gardened) selected for consumption by Seminole Indians in South Florida 
change between the end of the Seminole Wars and World War I? Due diligence has been made to locate all relevant primary sources, including documents and oral histories, in hopes of producing some answer by systematically analyzing observations and mentions of food consumption and taboos in them. My analysis of those data has resulted in development of a model that describes trends in food selection and the general trajectory of Seminole foodways during the period. That model is presented here. It is my hope that this work will (1) provide historians with baseline information upon which to evaluate relevant primary sources in the future and by which to re-evaluate related secondary sources, and (2) find use in Florida archaeology as a testable hypothesis and theoretical model by which to approach Seminole diet and historical ecology.

\section{Historical Background: The Seminole World between Removal and the First World War}

Florida's contemporary indigenous population stems from the absorption of remnant Indian groups and selfemancipated Black Americans by the southward-migrating Creek refugees of tribal conflicts during the late eighteenth and early nineteenth centuries (Frank, 2014, pp. 290, 292; Goggins, 1940, pp. 279; Mulroy, 2003, p. 8; Sturtevant, 1954). The "Seminole" moniker gained currency in the United States during the political buildup leading to the Seminole Wars. Those conflicts were waged between 1817 and 1857 with the aim of returning Black Seminoles to bondage, removing remaining Florida Indians to Oklahoma, and clearing the peninsula for American settlement (Frank 2014, p. 277; Weisman 2014, p. 393). Today's federally recognized Seminole and
Miccosukee tribes and the cluster of Seminole traditionalists known as the Independents descend from the indigenous people that remained in South Florida after the removal of thousands of their own to Oklahoma by the United States between the Second and Third Seminole Wars.

Prior to the Seminole Wars, thousands of Seminole Indians had come to inhabit the area between Lake Okeechobee, the Everglade swamplands, and the Florida Keys, though many continued to utilize the central portion of the state for grazing cattle and hunting (Figure 1). They tended to prefer hammock lands, small rises that remained dry during the wet season, over which to build their homes and gardens. They engaged in hunting, beef cattle husbandry, horticultural pursuits, and extensive trade with Spanish colonists, with whom they preferred to engage over Americans. Seminoles fashioned sea-going canoes capable of carrying as many as thirty people at a time to shores as far off as those of Cuba in trade. They offered their trading partners pelts, hides, dried fish, honey, and other items in exchange for rum, coffee, and sugar (Covington, 1959, pp. 116-117). Those trade networks broke down with the Adams-Onís Treaty, which ushered in an era of war, uncertainty, and granted Florida to the United States, and decreasing sedentism.

Removal was the final nail in the coffin of the old Seminole world, producing a distributed network of around two hundred or so individuals residing with what remained of their extended families in localized but often mobile camps. Florida hammock soils are typically fertile, however, and regular rains make dry gardening an especially productive endeavor in the region (Henderson, 1939; Joos, 1984, p. 220). Horticultural contri- 
Figure 1: Approximate range of densest Seminole habitation by the late nineteenth century based on Duncan (1898) and Nash (1932). Seminole cattlemen and hunters made use of central and northern lands as well, however to an unknown geographic extent.



butions to subsistence self-sufficiency were significant, as the size of the typical Seminole camp garden was between one- and four-square acres (Joos 1984, 220). The abundant availability of wild flora and fauna certainly contributed to Florida Indian self-sufficiency as well (Kersey, 1975, pp. 46-48; MacCauley, 1887, pp. 510-516; Sturtevant ,1956, p. 7). Multiple observers commented as to post-Removal Seminole subsistence abundance and their resultant good health and primitivist prosperity in the South Florida camps. With regard to his 1881 visit, ethnologist Clay MacCauley $(1887,504)$ noted that "the Seminole, living in a perennial summer, is never at a loss when he seeks something, and something good, to eat." Indian inspector A.J. Duncan (1898, p. 213) remarked decades after MacCauley's visit that "[Seminole] food is plentiful," describing wild duck, turkey, fish, and other game as abundant. Indian Agent Lorenzo Creel 
suggested in 1913 that the region's indigenous population "would be but little affected" if the Indians refused relocation to any nearby reservation due to their abundant surrounds and the strength of their system of subsistence (Nash, 1932, p. 65). While the decimation and trauma of Removal produced a society whose members were often hesitant to interact with the outside world, the abundance of the surrounding landscape surely alleviated that trauma to a degree by offering some nutritional and economic certainty.

Changes were on the horizon, however, even before MacCauley's visit, as American settlement in Florida had begun in earnest after the Civil War. Many observers were alarmed by the pace of settler encroachment, documenting their concerns. Naturalist Fred Ober sounded one of the earliest alarms in 1875. He argued that if the white Floridian "[extends] his encroachments further," that Seminoles would be unable to live in continued "peace and harmony with mankind, asking nothing, needing nothing" (Ober, 1876b, p. 173). It is tempting to write Ober off as proponent of the noble savage myth, but the naturalist's interpretive glasses were no less rose-colored than those of most other observers of turn-of-the-century Seminole food variety and abundance, economic life, and general health. Charles Stephens, illustrator and artifact collector, argued in 1883 that Seminole nutritional resource needs were few and "well supplied," begging his reader to understand that "all the Seminole asks is ... to enjoy his swampy solitude undisturbed" (Stephens, 1883, p.293). Solitude, it seems, never had a chance in the swamp, as white trading posts began slowly but surely to draw Seminole hunters from the peninsular interior during the late nineteenth century to acquire their pelts, plumes, and hides. While contact with white traders increased every decade alongside Seminole use of manufactured goods and foodstuffs, Seminole hesitance to introduce white influence in other aspects of their lives remained remarkably high. They generally deflected efforts at Christianization, Western modes of education, and re-settlement on reservation lands successfully until the 1920s.

A suite of political, social, and environmental factors taking root during the first eighteen years of that century led to the eventual about face. First, the reclamation and drainage of the South Florida swamps, starting in 1906, steadily decreased wetland acreage available for hunting, gathering, and horticulture along with the number of game animals on the landscape (Covington, 1973; p. 102; U.S. House, 1917, p. 24). Second, several acts of state and federal legislation passed between 1901 and 1918 served to slow and eventually halt plume bird hunting and the sale of related materials in key supply chain contexts (Cart, 1973; Doughty, 1972). Third, the value of alligator hides dropped precipitously by 1917 due to an influx of Central American hides for which there was no import duty (U.S. House, 1917, p. 24). Finally, better armed white trappers increasingly entered the South Floridian interior in search of hide animals and plume birds despite the bans, making indigenous hunters "a minority factor in the Florida fur trade" in short order (Nash, 1932, p. 36; U.S. House, 1917, p. 24). What was once a trickle of Seminoles leaving the camps in search of temporary wage labor on local farms, picking beans or tomatoes during lean times, became a steady stream of bodies reporting for duty as a result. Some found their way to "tourist camps," for better and for worse, where 
Seminoles and their crafts were on display for outsiders, often on the terms of paying white entrepreneurs. Forced to chain their fortunes to the enterprises of white Floridians, a pattern of dependence emerged that would spiral out of control by the Great Depression (Kersey, 1989, p. 36).

\section{Methods: Presence/Absence Analysis in Documentary Foodways Context}

A review of available documents and oral histories reveals that late nineteenth- and early twentieth-century South Florida hosted a diversity of edible wild flora and fauna and that much of its landscape was sufficiently fertile as to meet the subsistence needs of its indigenous population. This study borrows the use of presence/absence matrices from the archaeological subfields of zooarchaeology and paleoethnobotany to facilitate analysis of food types present in indigenous South Florida diets over time, treating chronologized documents as temporal "strata." It analyzes Seminole oral histories in relation to foodways for the period as well, tapping dozens of relevant transcripts of interviews of Seminole and Miccosukee tribal members carried out between the 1960s and 1990s. Those two lines of evidence are evaluated in the Results and Discussion sections below in relation to this study's central research question.

Among the over two dozen known documents describing daily life in indigenous South Florida between 1855 and 1917 , a subset of eighteen contain unambiguous discussions of Seminole procurement, cultivation, preparation, or consumption of food and related raw materials (Appendix A). The next section's analysis operates on the premise that documentation by observers of Seminole food types indicates that the plant or animal species represented by those foods existed in sufficient numbers, and within a reasonable enough geographic range, to allow for their ready procurement in the region at the time. In this paper, I draw inferences from the presence of documented observations of food items and, to a lesser degree, from their absence, but I do not utilize either indicator option as an index for frequency or firm measure of relative abundance. It is important to note here that traded foodstuffs were introduced during the latter portion of the period and later became important aspects of the Seminole diet (House, 1917, p. 51; Kersey, 1975, p. 42; Joos 1984). However, much is known regarding Seminole trade with coastal merchants but decidedly less is known as to Seminole subsistence self-sufficiency during the same period. This study focuses on those food types available to Seminole populations via hunting, gathering, and gardening in hopes of providing a more balanced picture of Seminole subsistence over that time.

This study does not explore dishes or recipes, opting instead to list their clearly defined constituent food components upon encounter in the documents, but only if they may be gleaned or parsed out with confidence. MacCauley's notes regarding Seminole children's domestic contributions to camp life, for example, that they were expected to "stir . . . soup while boiling" and "aid in kneading the dough for bread," say little with respect to the plant and animal species that make up those dishes, making the observations unavailable for this analysis (1887, p. 498). This study does not generally address misrecognitions of food types by observers or foodways illegibility, opting to reduce the potential for error in interpretation by striking ambiguities 
rather than exploring them in this iteration of the research. I tabulate mentions of the items discussed in the documents and chronologize observations by document date, producing a visual timeline of Seminole foodways. That timeline is organized by the presumed origin of food source species, wild or domesticated, in the context of indigenous South Florida. Food item origin is important, as the nature of food acquisition among Seminoles was gendered, with men usually hunting and fishing while women typically gathered wild plants, cultivated fields, and prepared food for consumption (Covington, 1993, p. 8). Since precise taxonomic designations are not often expressed or even discernible in the documents evaluated, common Western culinary distinctions serve as the primary food item classification here while species designations are offered secondarily (Appendix B).

I recognize this study's limitations in terms of geography and culture. Seminole camps and communities were distributed across the ecologically diverse South Florida landscape during the period in question, often differing in culture and language from one village to the next. The documents investigated here describe brief visitations made by outsiders to the region. They tend as a result to include little discussion as to camp, village, locational, linguistic, or cultural specifics, with the exception of the accounts of Indian agents and ethnologists $(n=6)$. Without any common degree of locational clarity or cultural and linguistic specificity across documents, the resulting analysis is a coarse-grained one. I plan to expand on the study in the future, analyzing comparatively localized patterns of food consumption against more specific linguistic, cultural, and ecological contexts. I discuss the prospect more fully in the Conclusion and Future Directions section of this paper.

The coarse-grained nature of document aggregation and analysis here does not reduce the utility of oral-historical study. In fact, the resultant documentary ambiguity mirrors the broad temporal and regional scale of Seminole social memory as to late nineteenth- and early twentieth-century diet and foodways. The oral histories cited below stem from the digital archive of the Samuel Proctor Oral History Program (SPOHP) at the University of Florida and include the voices of Seminole and Miccosukee tribal members as well as of merchants, missionaries, lawyers, historians, and other outsiders who maintained very close contact with tribal members over the twentieth century. In most cases, transcribed oral histories serve to corroborate what is reflected in the documents, confirming that food types observed by outsiders during the period exist in the world of Seminole social memory. The SPOHP Seminole Oral History Collection includes two hundred and fifty-one digital transcripts of interviews and other recordings. I have identified twenty-nine recordings containing references to Seminole foodways unambiguously connected to the period of interest where individual food items are mentioned or are clearly alluded to as ingredients in some dish or recipe. Of those, sixteen include some mention of food types not documented by outside visitors during the period as reflected in historical documentation. Analysis of those data serves this study by providing a check against the blind spots and biases of related documents and greatly augments the historical dietary inventory constructed here. Due to the fuzzy nature of oral historical timelines and the temporal distance between the oral historical date range and the period under study, 
that data set cannot serve to refine the incidence chronology reflected in analysis below. The oral histories do, however, raise important questions about the story of Seminole foodways as reflected in historical documentary accounts. The various oral-historical elucidations of traditional Seminole food taboos serve in some cases to contradict the inventory developed here. The methods employed in this study are imperfect, especially considering the potential for oral historical inaccuracy, but they are intended to serve only as a point of departure from which future historical and archaeological studies of Seminole foodways may come to build.

\section{Results: A Summary of Locally Available Food between 1855 and 1917}

Documentation of Seminole foods of hunted or foraged origin (Table 1) reflects a greater diversity of species than documentation of foods linked to domesticated plants and animals for the period. Twenty-eight hunted or foraged food types, each connected to distinct plant or animal taxa, were documented by historical observers as compared to the twenty food types recorded by them of domesticated origin. Mention of the acquisition and consumption of the edible flesh of white tailed deer, known as venison, is regular across the span of the documentary study $(n=11)$ and is only rivaled in regularity of observation by that of wild turkey $(n=8)$. Other terrestrial game meat noted by outside observers includes that of bear, duck, opossum, quail, rabbit, squirrel, and of unspecified species of wild bird and wild bird egg. Terrestrial game potentially considered taboo during the period (Table 2) includes snake, snake egg, dog, and, despite a documented observation to the contrary, rabbit. Interestingly, MacCauley (1887) is the only observer to note the inclusion of opossum, rabbit, and squirrel in the Seminole diet.

The document set suggests that Seminoles had access to a variety of marine-based meat animals, including various species of turtles, fish, and mollusks alongside manatees and alligators. The American alligator $(n=7)$, symbol of the South Florida swamps, was documented by observers in the context of consumption nearly as frequently over time as wild turkey $(n=8)$. Fish were observed by visitors to the region in greater numbers and with some regularity, including numerous observations of fish of unknown species $(n=7)$ over time and more specific mentions of black bass $(n=2)$ and trout (mentioned by MacCauley alone, $\mathrm{n}=1$ ). Related oral histories may serve to further refine our understanding of the variety of fish available to Seminoles during the period, as Florida gar and Florida mullet receive repeated mention in oral histories as strong preferences $(n=6$ and $n=2$ respectively) alongside possible preferences for catfish $(n=1)$ and tarpon $(n=1)$. Despite the persistence of alligator meat in documented observation over time, alligator is noted in some oral history transcripts (Table 2) as something other than a primary preference.

Seminoles caught fish, alligators, and small turtles by spearing from the inside of their canoes (Densmore, 1956, p. 21; Duncan, 1898, p. 223). The capture of gopher tortoises, however, was a more complicated endeavor involving several people working in concert to remove an entrenched giant from its den (Durham, 1975, p. 11). Documented observations of terrapin, freshwater turtles common in the region, and gopher tortoise, bookend the period $(n=6)$. Other marine-based animal meats observed in the context of 
Table 1: Seminole foods of hunted or foraged origin observed between 1855 and 1913.

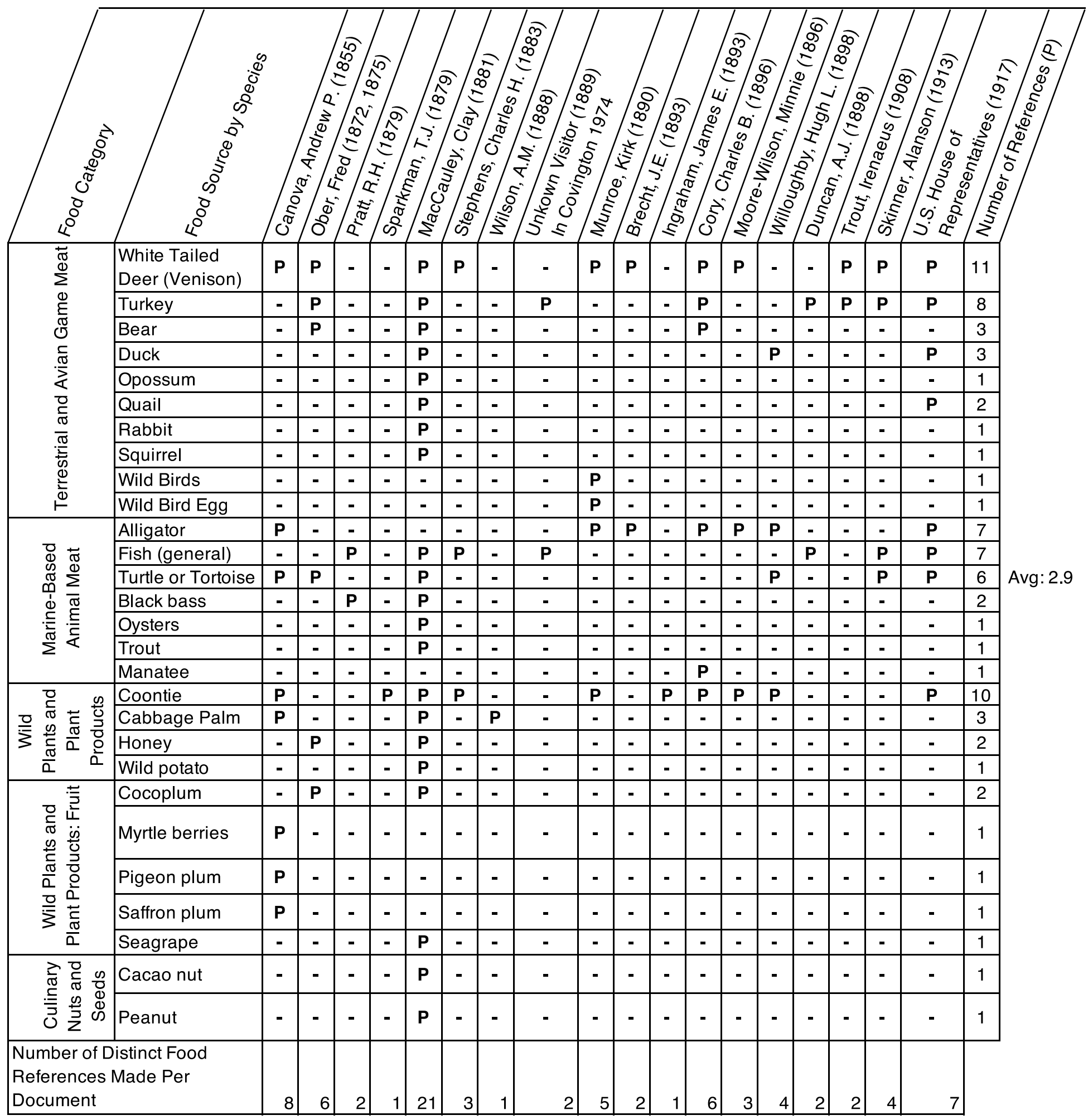

P Present (documented in direct relation to consumption as food by observers)

- Absent (no mention made of food item or species in direct relation to consumption as food by observers)

Gonzalez, A.D. (2021) Seminole Food: Patterns of Indigenous Foodways in South Florida, 1855 to 1917. New Florida Journal of Anthropology 1(2),47-71 DOI 10.32473/nfja.v112.123723 
Table 2: Seminole food taboos noted in SPOHP Seminole Oral History Collection interviews.



T Absolute food taboo based on interviewee's personal knowledge.

Pr Preference to avoid the food item in question. Assertion made based on insider knowledge or evidence.

S Suspected preference to avoid food item based on interviewee inference.

- No mention made of food item or species in relation to consumption as food. consumption by visiting outsiders include oyster and manatee, though mentions of each are few in both documents and oral histories. Notably lacking from the list of documented food observations are specifics as to bird species consumed by Seminole Indians. Oral history may provide some suggestion here, as one account notes the existence of long-billed curlew in the Seminole diet of the time.

Strangely, a larger number of distinct references to food taboos and avoidances associated with avian game meat are found in oral-historical records than there are mentions of avian game species consumed in all evaluated primary sources. Related food restrictions (Table
2) include taboos against the consumption of crane and owl, and avoidances of turkey -- a surprising thing considering turkey's regular appearance in historical accounts -- and duck. Consumption of one's own clan animal, at the time one of twelve food possibilities: snake, alligator, panther, blue heron, bear, otter, yellow bird, wolf, frog, blackbird, wildcat, or deer, seems to have been forbidden as well (Weisman, 2007, p. 200).

The tuberous root of the wildgrowing coontie plant, a cycad of supreme subsistence and cosmological significance to the Seminoles historically, is mentioned by outside observers with relative consistency over time $(n=10)$. 
Nineteenth-century Seminole medicine men told a richly syncretic story of coontie's origins, noting that Christ himself introduced the root to the tribe (MacCauley, 1887, p. 519). Descending upon them at Cape Florida, he was met by three Indians who carried him on their shoulders, the perch from which he sowed the first coontie seeds over South Florida's vast and various landscapes (Moore-Wilson, 1896, pp. 165-166). Coontie was used to produce a caloriedense bread, but its product did not come easily. Processing coontie was a labor and resource intensive operation, requiring a program of pounding and straining to remove its powerful constituent neurotoxin, cycasin (Gifford 1944, p. 36). Despite the ready availability of numerous other nutritionally rich foods, Seminole Indians relied heavily on coontie until the twentieth century. Cabbage palm, on the other hand, Florida's state tree and its most abundant palm, containing a substantial and edible heart, was only noticed by outside observers on three occasions between 1855 and 1888. Despite its relative ubiquity across the state, cabbage palm produces as insignificant a signal in the oral record (Chauduri, n.d., p. 2; D. T., 1971, p. 7) as the documentary one. Outsiders also documented the consumption of non-traded honey, wild potatoes and multiple observed classes of wild fruits, culinary nuts, and seeds on the part of Seminoles, but only infrequently and largely prior to 1888. Oral histories (Table 3) expand upon that story, however, adding that hickory nuts, acorns, pecans, sumac berries, huckleberries, blackberries, and sassafras root bark were foraged from the wild by Florida's indigenous populations. Seminoles consumed a less diverse group of food types produced from domesticated sources during the period (Table 4) but appear to have done so with greater consistency. Historical observers mention corn $(n=12)$, which was usually parched and ground to produce a nutritious soup known as sofkee, in most of the accounts of the documentary dataset. Corn was on par with coontie in terms of its dietary importance and significance in the realms of Seminole history and cosmology. The plant and its consumption were central to the annual tradition of the Green Corn Ceremony, a redistributive feast inherited from their Mississippian ancestors (Ethridge, 2003, p. 125; Hudson, 1984). Corn also served to solidify marriage unions among Seminoles, as brides offered corn to their husbands-to-be, promising "I will provide the bread if you furnish the meat" (Canova 1855, p. 106). In those ways corn served as a central aspect of Seminole social cohesion.

Banana $(n=8)$, sugar cane $(n=7)$, pumpkin $(n=6)$, and sweet potato $(n=5)$ were also identified by observers at rates at or above average, while the cultivation of non-pumpkin squash varieties and beans appears to have been a low priority amount Seminoles at the time, hardly drawing outside notice. The oral histories add some texture here in terms of legume variety, with several interviewees describing the cultivation by historical Indians of butter beans, sweet peas, and lima beans. Seminoles produced a diverse array of bananas. By their own taxonomy they raised average bananas, dwarf bananas, red bananas, and grey bananas (Sturtevant, 1954, p. 441). Banana plants hold an important place in Seminole memory, as the Third Seminole War was said to have been catalyzed by provocation on the part of American soldiers in the form of the destruction of the prized banana plants of Chief Billy Bowlegs, reportedly "the delight and solace of the chief's heart" (Canova, 1855, 
p. 6; Kersey, 1974, p. 5). The oral-historical record adds white potatoes $(n=2)$ to the inventory of food items of domesticated origin. White potatoes either went $(n=2)$ to the inventory of food items of domesticated origin. White potatoes either went entirely unnoticed by historical observers or were mistaken for wild ones. Except for the general category of melon $(n=4)$, average numbers when counted visitors reported seeing fruits in below by distinct species. Mention of domesticated fruits more generally $(n=15)$, however, outnumbers that of any one individual plant species over time. Nonmelon fruits documented by observers include lemon, orange, guava, lime, pineapple, and grape. MacCauley (1887, p. 504) reports the only instance of lime, pineapple, and grape consumption a-

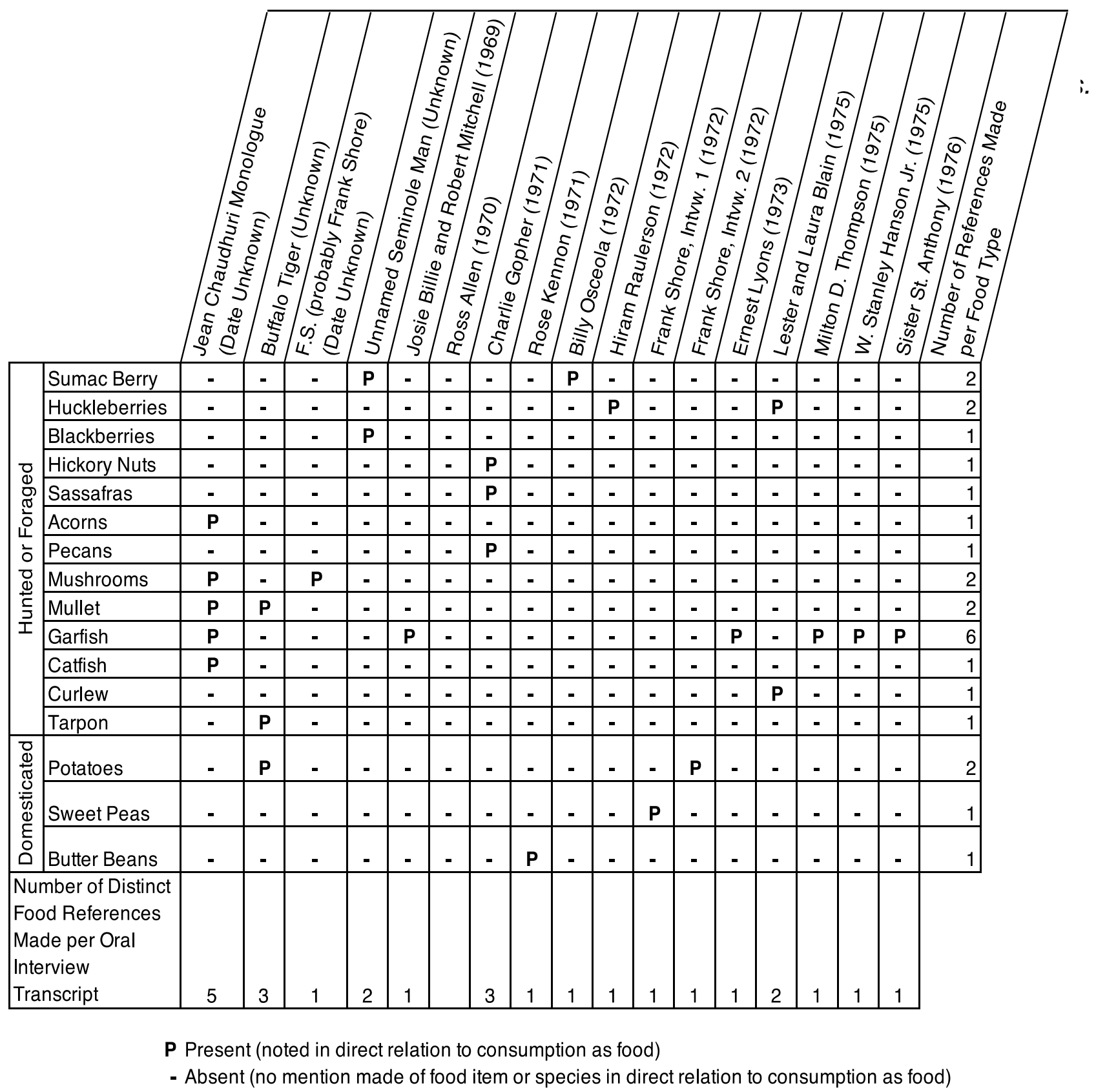

Gonzalez, A.D. (2021) Seminole Food: Patterns of Indigenous Foodways in South Florida, 1855 to 1917. New Florida Journal of Anthropology 1(2),47-71 DOI 10.32473/nfja.v112.123723 
mong all documents in the subset.

Of domesticated animal meats consumed by Seminoles, observations by outsiders of dietary pork $(n=12)$ amount to more than twice that of chicken $(n=6)$ and nearly three times the mentions of beef $(n=5)$. Observers rarely documented avian eggs in consumption $(n=2)$, on the other hand, a difficult thing to imagine considering the number of chickens typically present at camp. Pigs and chickens roamed about with relative freedom in Seminole camps, representing easy access to valuable nourishment. Indian Inspector W.S. Coleman (U.S. House, 1917, p. 5) suggested halfjokingly that they did so "on democratic equality" with camp inhabitants, and that when Seminole camps were on the move that "the pigs and chickens are carried with them" (U.S. House, 1917 p. 5). The ancestral Creek population drove large

Table 4: Seminole foods of domestic origin observed between 1855 and 1913.

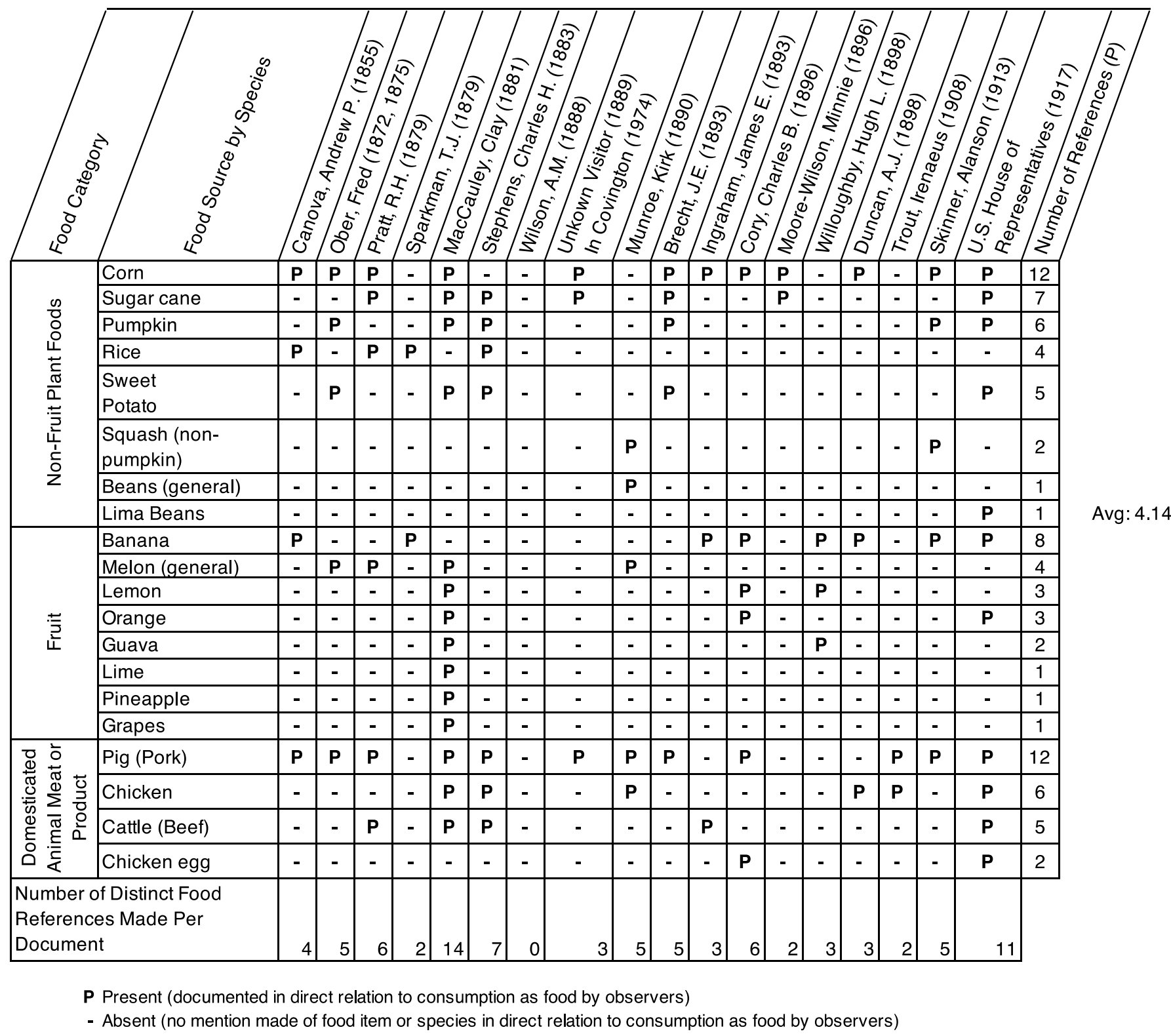

Gonzalez, A.D. (2021) Seminole Food: Patterns of Indigenous Foodways in South Florida, 1855 to 1917. New Florida Journal of Anthropology 1(2),47-71 DOI 10.32473/nfja.v112.123723 
herds of cattle toward South Florida during the century prior (Sattler, 1996, p. 50). Post-Removal Seminoles located and maintained the remnant populations of those herds, though no large cattle ranching operations would reappear among them until the mid-twentieth century (Frank, 2017).

\section{Discussion: Building a Model of Seminole Foodways}

Considered alongside oral-historical data, documentation of Seminole diet made by outside observers between 1855 and 1917 reveals a remarkable general consistency in the selection of locally available food types, wild and domesticated (Figure 2). It may also reflect the gradual decline in availability or preference for a subset of food types during the period. Documented observations of hunted or foraged foods by type yield an average of roughly three observations per type in aggregation. Food types at or below the average number tend to drop off by 1887 , including seven categories of terrestrial and avian game meat, four types of marine based animal meat, three wild-plant-based foods, and all culinary nuts. The record of wild fruit, culinary nut, wild potato, and cabbage palm consumption is temporally ephemeral, limited to the three decades following the Seminole Wars. Perhaps those were foods of convenience, consumed during a time when some degree of nomadism was essential in ensuring survival by minimizing exposure to whites. The assertion is further supported by MacCauley's (1887) observation of Seminole consumption of quail and squirrel alongside the potentially taboo-restricted meat of opossum and rabbit. Except for the mention of quail in 1917, no other observations beyond MacCauley's of the consumption of those animals was documented.
Those wild foods for which observations across documents number greater than three include venison (white tailed deer), turkey, alligator, turtle or gopher tortoise, and coontie. It is notable that, when historical observations of fish are aggregated rather than listed separately by species, fish as a category unto itself appears in the record with greater frequency than all categories other than venison and coontie. The presence of alligator in the aggregated list is surprising considering oral-historical evidence of a strong preference for avoidance of alligator meat in all but the leanest times (Durham, 1975, p. 11; Osceola, n.d., p. 10). The confusion is compounded by the pattern of the item's appearance in the historical record, as only one mention exists of alligator as likely food before 1890 . It is possible that observations of alligator remains procured for trade with whites were at times conflated with flesh meant for consumption. Deer may be overrepresented here for the same reason, as deer skin and venison both possessed great value in trade. It may alternately be the case that, despite a possible preference against alligator consumption, Seminoles could not bring themselves to waste the edible portions of the alligators they hunted for trade. Allowing venison to rot, on the other hand, would undoubtedly have been an unforgiveable thing, making it more likely that venison was indeed an indigenous staple during the period following removal.

Documented observations of foods stemming from domesticated plants and animals by type yield an average of roughly four observations per type in aggregation. Food types at or below the average number tend to pick up largely after 1890 with few mentions prior, including three non-fruit plant foods, all non-banana fruits by individual 
Figure 2. Two-channel model of Seminole foodways between 1855 and 1917.

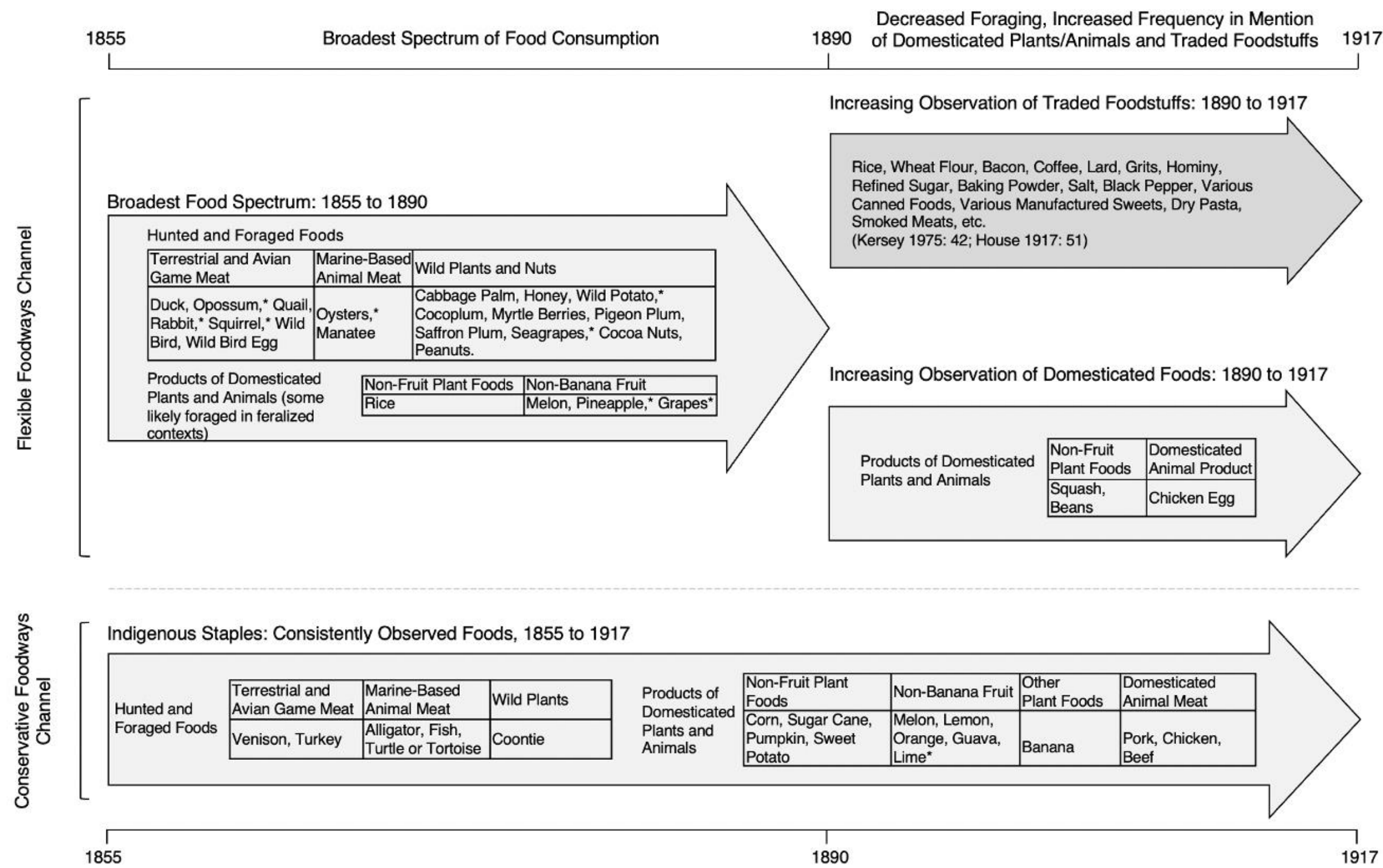

*Indicates that food type was only observed by MacCauley (1881).

Gonzalez, A.D. (2021) Seminole Food: Patterns of Indigenous Foodways in South Florida, 1855 to 1917. New Florida Journal of Anthropology 60 1(2),46-70 DOI 10.32473/nfja.v1i2.123723 
species, rice, and chicken eggs. As with fish among wild foods, evaluating domesticated fruit by species may produce the initial impression that their consumption was rare or that documentation is spotty. Considered in aggregation, on the other hand, non-banana fruit as a general category is only exceeded in incidental frequency by corn, banana, and pork. Furthermore, the categorization of both nonbanana fruit types and rice as domesticated foods is potentially misleading, as it is likely that some of those observations were of foods foraged by Indians in feralized contexts. That may explain the contra-trajectory of rice in analysis as domesticated food here, following the same pattern of observation of the least mentioned wild foods and dropping off by or before 1890 . The sparce historical observation of beans of any type in culinary context $(n=2)$ is of interest here as well, there being no shortage of oral histories noting the consumption of beans during the period and illustrating their diversity in consumption at Seminole camps (F.S., n.d., p. 7; Kennon 1971, p. 24; Shore, 1972b, p. 13). The emergence of beans in the historical record alongside nonpumpkin squash and chicken eggs indicates a possible increase in Seminole reliance on food stemming from domesticated species over those of wild species relied on in previous decades. Consistently observed food items of domesticated origin include five non-fruit plant foods (corn, sugar cane, pumpkin, and sweet potato), banana, and three animal meats (pork, chicken, and beef). Adding non-banana fruit as an aggregated category to represent the persistent selection of sugary foods on the part of Seminole Indians over the course of the period's span rounds the list out. Though, as mentioned above, many of those items may have been foraged in feralized contexts.
Analysis of observations of Seminole food recorded between the end of the Seminole Wars and World War I reveals that the corpus of foods selected among locally available options, wild or garden grown, changed in several important ways over that time (Figure 2). Seminole Indians maintained the broadest spectrum of food consumption between 1855 and 1890, including the consumption of some foods restricted by taboo or described in oral historical accounts as typically avoided. The period between 1890 and 1917, on the other hand, likely represents one of transition as evidenced by decreasing reports of hunted and foraged food consumption and a seeming increase in reliance on foods of domesticated origin.

Despite those changes, a suite of foods saw consistent or near-consistent reporting over the entire period. Those include (1) hunted and foraged staples such as venison, turkey, alligator, fish, turtle and tortoise, and coontie, and (2) domesticated plants and animals such as corn, sugar cane, pumpkin, sweet potato, banana and a host of other fruits, pork, chicken, and beef (Figure 2). The arc of the Seminole food trajectory for the period was likely shaped by numerous factors, but two stand out as perhaps most weighty. First, the destruction, depopulation, and disorder introduced by the Seminole Wars produced a society vastly different in terms of numbers, organization, and subsistence than that which existed prior. It was Seminole economic prosperity in terms of livestock that drew American eyes southward toward Florida in the first place (Weisman, 2014, p. 400). Decades of intermittent war reduced that prosperity significantly by making wholly sedentary life impossibly difficult. The forcible removal of most of Florida's indigenous population to Okla- 
homa left as few as two hundred Seminoles to rebuild. Those holdouts were punished for their refusal to surrender by the destruction of their supplies, crops, homes, and camps (Lawson, 2011, Chapter 15, para. 14-18). It seems likely, then, that the period between 1855 and 1890 was one of relative subsistence flexibility, where Seminole Indians greatly supplemented their staple diet by expanding the range of wild species they hunted and gathered.

The later period, 1890 to 1917 , appears to reflect marked change in terms of Seminole selection of locally available food. The period was characterized by a shift in the mode by which staple foods were supplemented, moving from supplementation via expanded hunted and foraged options to supplementation by a combination of expansion in homegrown food options and the incorporation of manufactured foods procured in trade (Figure 2). The earliest South Florida trading posts appeared in the 1870 s, becoming relatively common by the 1890 s. Their presence drew Indians from their camps in the interior to trade pelts, plumes, and hides with newly established American merchants (Kersey, 1975, pp. $29,47)$. Seminoles were prolific hunters of the animals prized by those traders, including alligator, otter, deer, and various birds, killing them by the thousands annually (Kersey, 1975, pp. 46-48). In exchange, they incorporated a diverse array of manufactured foods including wheat flour, bacon, coffee, lard, grits, refined sugar, salt, black pepper, various manufactured sweets, dry pasta, and smoked meats into their diet (Figure 2). The question of why foods acquired at trading posts came to replace non-staple hunted and gathered foods during that time is an important one, as Seminoles were, even as late as the 1890s, famously hesitant to tie their fortunes too closely to white enterprises. It may be that the volume of time spent by Seminoles hunting and preparing pelts, plumes, and hides for market and getting them there came to equal or surpass that of past subsistence hunting, leaving little time or energy for maintenance of quite as broad a spectrum of meat types in their diet. It may also be the case that traded foodstuffs came to replace the wild plants and nuts that were foraged by Florida Indians prior to 1890. Whatever the case, the pattern revealed here is not necessarily one reflective of rapid descent into dependance. More likely it represents a single temporal slice the continuous negotiation and re-negotiation of foodways as one aspect of Seminole culture.

\section{Conclusion and Future Directions: Taking the Model to Task}

This paper taps extensive documentary and oral historical evidence to suggest that two complimentary channels of foodways existed among Seminole Indians in South Florida between 1855 and 1917: (1) a conservative channel that may have maintained symbolically and nutritionally important foods like coontie, pork, and banana and (2) a more flexible channel that allowed for the incorporation of supplementary foods of various origins, including manufactured foods, and the removal of others. It proposes an historical model of Seminole dietary transition by carefully describing each strain's constituent components and changes to those components over time, filling the foodways gap in historical knowledge in the process.

Future historical studies may easily come to refine the model by seeking additional documentary and oral historical sources, additional contextual clues 
in the existing sources, and for errors in the current interpretation of evaluated materials. For Florida historical zooarchaeology, archaeobotany, and historical ecology this model may serve as an observational hypothesis, driving future studies of Seminole diet and environment by providing testable historical observations for the period in question and as a comparison point against archaeological and historical studies of other periods (Weisman, 1989; Joos, 1984). Archaeologists may also use the model as a baseline from which to understand local synchronic camp-level variance (Fenno et al., 2017) against the more general Seminole foodways pattern as described here. In addition, this study creates a rare opportunity for historical archaeological investigations of human behavioral ecology in relation to nineteenth- and twentieth-century Indian hunting, gathering, and trading practices by providing baseline data upon which to build resource ranking schema. Finally, this work will serve to broaden pedagogical and research methods in history and archaeology by opening the door to crowdsourced distribution of documentary research in relation to Seminole foodways. As the majority of relevant documentary sources are archived in electronic form, I plan for this research to manifest in the next iteration as an online documentbased "field school," assigning ranges of documents as course work for undergraduate and graduate students who will work to "excavate" documentary strata as I have here and begin the work of analysis against related gray literature. I plan, furthermore, to glean a listing of ancillary foods and food species as implied by observations of Seminole dishes with known recipes in the process. The project has produced not only a model, then, but an invitation to scholars and students to use it in historical, archaeological, and even pedagogical application, shattering, supporting, or modifying the model in the process. Considering that the period has attracted almost no other scholars in analysis of Seminole foodways for decades, the model presented here may serve to finally draw analysts in by posing its generalizing hypothesis of two-channel Seminole historical food consumption.

\section{Acknowledgements}

I owe a debt of gratitude to Brandy Norton for introducing me to the repository of the Samuel Proctor Oral History Program and for suggesting that I prioritize Seminole food restrictions here. Dave Scheidecker's comments on the oldest iteration of this paper and our subsequent conversations on the topic have been immensely helpful and influential as well. I thank the Seminole Tribal Historic Preservation Office more generally for their patience, for their helpful responses to my queries, and for their kindness in allowing me to visit their facilities in person. I thank Di Hu, Natalie Ingraham, and Jessica Santone for reviewing the first iteration of this paper and for our subsequent discussions. I am grateful for the help of my students, Melissa GrijalvaForeman and Heather Militello, in bibliographic research and editing. I am also thankful for the comments of my anonymous reviewers, which have greatly strengthened the manuscript. Finally, I am most thankful to Arielle Gonzalez, who has consistently acted as a sounding board for my ideas on the topic of Seminole foodways, from this paper's first iteration to its most recent branching. 


\section{References}

Allen, R. (1971, November 11) Interview with Ross Allen [Interview]. Samuel Proctor Oral History Program, Seminole Oral History Collection, University of Florida. https://ufdc.ufl.edu/UF00007888.

Bennett, B. C. (2015) Subsistence Farming in Southern Florida (1840-1940): The Importance of Sweet Potato-In Memory of Daniel F. Austin. Economic Botany, 69(2), 185-198. DOI: 10.1007/s12231-015-9312-0

Beaver, F. (1971, March 15) Interview with Fred Beaver [Interview]. Samuel Proctor Oral History Program, Seminole Oral History Collection, University of Florida.

https://ufdc.ufl.edu/UF00007908.

Beverly (Ober), F. (1876a) Among the Seminoles. In Camp Life in Florida: A Handbook for Sportsmen and Settlers, compiled by Charles Hallock (179-193). Forest and Stream Publishing Company. DOI: 10.5962/bhl.title.18983

Beverly (Ober), F. (1876b) In the Cypress Swamps. In Camp Life in Florida: A Handbook for Sportsmen and Settlers, compiled by Charles Hallock (194-200). Forest and Stream Publishing Company. DOI: 10.5962/bhl.title.18983

Billie. (1971) Interview with Billie [Interview]. Samuel Proctor Oral History Program, Seminole Oral History Collection, University of Florida. https://ufdc.ufl.edu/UF00008163.

Billie, J. and Mitchell, R. (1969, April 25) Interview with Josie Billie and Robert Mitchell [Interview]. Samuel Proctor Oral History Program, Seminole Oral History Collection, University of Florida.

https://ufdc.ufl.edu/UF00007895.

Blain. L. and Blain, L. (1975, December 13) Interview with Lester and Laura Blain [Interview]. Samuel Proctor Oral History Program, Seminole Oral History Collection, University of Florida. https://ufdc.ufl.edu/UF00008015.

Brecht, J.E. (1893) Report as to Seminoles in Florida. August 11, 1893. In Annual Report to the Department of the Interior. United
States Department of the Interior, 356-359. http://digital.library. wisc.edu/1711.dl/History.AnnRep93.

Briggs, R.V. (2015) The Hominy Foodway of the Historic Native Eastern Woodlands. Native South, 8(1), 112-146.

DOI: $10.1353 /$ nso.2015.0004.

Brown, F. (1971, September 24) Interview with Mr. Frank Brown [Interview]. Samuel Proctor Oral History Program, Seminole Oral History Collection, University of Florida. https://ufdc.ufl.edu/UF00007929.

Canova, A P. (1855) Life and Adventures in South Florida. Tribune Printing Co. https://archive.org/details/lifeadventuresin00cano.

Cart, T.W. (1973) The Lacey Act: America's First Nationwide Wildlife Statute. Forest History Newsletter, 17(3), October, 4-13. DOI: $10.2307 / 4004266$

Chauduri, J. (n.d.) Monologue with Jean Chauduri [Interview]. Samuel Proctor Oral History Program, Seminole Oral History Collection, University of Florida. https://ufdc.ufl.edu/UF00007924.

Cory, C. B. (1896) Hunting and Fishing in Florida. Estes \& Lauriat. DOI: 10.5962/bhl.title. 20247

Covington, J. W. (1993) The Seminoles of Florida. University Press of Florida. http://ufdc.ufl.edu/AA00061379/00001.

Covington, J. (1974). Florida Seminoles: 19001920. The Florida Historical Quarterly, 53(2), 181-197. http://www.jstor.org/stable/30149800.

Covington, J. W. (1973) The Seminole Indians in 1908. The Florida Anthropologist 26 (3) September, 99-104. https://ufdc.ufl.edu/UF00027829/00165/14j.

Covington, J. W. (1959) Trade Relations between Southwestern Florida and Cuba: 1600-1840 The Florida Historical Quarterly 38(2), Oct., 114-128. http://www.jstor.org/stable/30139020. 
D. T. (1971, May) Interview with D. T. [Interview]. Samuel Proctor Oral History Program, Seminole Oral History Collection, University of Florida. https://ufdc.ufl.edu/UF00008164.

Densmore, F. (1956) Seminole Music. United States Government Printing Office. https://ufdc.ufl.edu/FS00000025/00001/1j.

Doughty, R. W. (1972) Concern for Fashionable Feathers. Forest History Newsletter, 16(2), 4-11. DOI: $10.2307 / 4004150$

DuBois, J. (1972, December 14) Interview with John DuBois [Interview]. Samuel Proctor Oral History Program, Seminole Oral History Collection, University of Florida. https://ufdc.ufl.edu/UF00007982.

Duncan, A.J. (1898) United States Supervision of Seminoles. In Report of the Secretary of the Interior for the Fiscal Year Ended June 20, 1897, 218-225. Washington, D.C.: Government Printing Office. https://www.google.com/books/edition/Annual_Report_The_Secretary_of_the_Inter/e3wvAAAAYAAJ?hl.

Durham, J. (1975, November 3) Interview with John Durham [Interview]. Samuel Proctor Oral History Program, Seminole Oral History Collection, University of Florida. https://ufdc.ufl.edu/UF00008012.

Ethridge, R. (2003) Creek Country: The Creek Indians and Their World. The University of North Carolina Press. https://ebookcentral.proquest.com/lib/csueastbay/reader.action?doclD=837903.

F. S. (n.d.) Interview with F. S. Samuel Proctor Oral History Program, Seminole Oral History Collection, University of Florida.

Fenno, M. G. (2013a) A Phase I Cultural Resource Survey and Assessment of the Connie Whidden Lease Modification, Brighton Reservation, Florida. Seminole Tribe of Florida.

Fenno, M. G. (2013b) Tribal Register Narrative Form and Narrative Statement: Tom Smith Camp. Seminole Tribe of Florida.
Fenno, M. G. (2017) Camp Life: Recording Historic Camps as Heritage. In Backhouse, P. et al. (Eds.), We Come for Good: Archaeology and Tribal Historic Preservation at the Seminole Tribe of Florida (pp. 135-157). DOI: 10.5744/florida/9780813062280.001.0001

Frank, A. (2014) Creating a Seminole Enemy: Ethnic and Racial Diversity in the Conquest of Florida, Florida International University Law Review 9, 277-293. DOI: 10.25148/lawrev.9.2.9

Frank, A. (2017) Modern by Tradition: Seminole Innovation in the Contemporary South. Native South, 10. DOI: 10.1353/nso.2017.0005

Gifford, J. E. (1944) Five Plants Essential to the Indians and Early Settlers of Florida. Tequesta 4, 36-44. http://digitalcollections.fiu.edu/tequesta/files/1944/44_1_03.pdf.

Gopher, C. (1971, May) Interview with Charlie Gopher [Interview]. Samuel Proctor Oral History Program, Seminole Oral History Collection, University of Florida. https://ufdc.ufl.edu/UF00007906.

Goggins, J. M. (1940) The Tekesta Indians of Southern Florida. Florida Historical Quarterly, 18(4), April, 274-284.

https://www.jstor.org/stable/30138346.

Green, R. (2008) Mother Corn and the Dixie Pig: Native Food in the Native South. Southern Cultures, 14(4), Winter, 114-126. DOI: 10.1353/scu.0.0027.

Hanson, W. S. (1975) Interview with W. Stanley Hanson, Jr., June 25, 1975. Samuel Proctor Oral History Program, Seminole Oral History Collection, University of Florida. https://ufdc.ufl.edu/UF00008009

Henderson, J. R. (1939) The Soils of Florida. University of Florida Agricultural Experimental Station Bulletin 334. University of Florida. https://ufdc.ufl.edu/UF00015113.

Hudson, C. (1984) Elements of Southeastern Indian Religion. Vol. 10, bk. 1, Iconography of Religions. E.J. Brill. 
Joos, S. K. (1984) Economic, Social, and Cultural Factors in the Analysis of Disease: Dietary Change and Diabetes Mellitus among the Florida Seminole Indians. In L. K. Brown and K. Mussell (Eds.), Ethnic and Regional Foodways in the United States: The Performance of Group Identity (pp. 217-237). University of Tennessee Press.

Kennon, R. (1975, September 25) Interview with Rose Kennon [Interview]. Samuel Proctor Oral History Program, Seminole Oral History Collection, University of Florida. https://ufdc.ufl.edu/UF00007928.

Kersey, H. A. (1975) Pelts, Plumes, and Hides: White Traders among the Seminole Indians, 1870-1930. University Presses of Florida.

Kersey, H. A. (1989) The Florida Seminoles and the New Deal, 1933-1942. University Press Florida 1989.

Lammie, J. (2018) Foodways in a Third Space. Conference of the Society for Historical Archaeology, Albuquerque, NM.

Lyons, E. (1973, August 3) Interview with Ernest Lyons [Interview]. Samuel Proctor Oral History Program, Seminole Oral History Collection, University of Florida. https://ufdc.ufl.edu/UF00007971.

Lawson, K. E. (2011) For Christ and Country: A Biography of Brigadier General Gustavus Loomis. Ambassador International.

MacCauley, C. (1887) The Seminole Indians of Florida. In Fifth Annual Report of the Bureau of Ethnology to the Secretary of the Smithsonian Institution. Washington, D.C.: United States Government Printing Office (1887): 469-531. https://digitalcommons.law.ou.edu/indianserialset/7210/.

Marconi, R. A. (2012) Palm Beach Museum Founder and Golfer the Forgotten Charles Barney Cory. The Tustenegee 3(1) April, 2028. http://www. pbchistoryonline.org/uploads/file/Charles\%20Barney\%20Cory.pdf.

Mihesuah, D. A. (2015) Sustenance and Health among the Five Tribes in Indian Territory, Postremoval to Statehood. Ethnohistory
62(2), 263-284. DOI: 10.1215/001418012854317

Moore-Wilson, M. (1914) The Seminoles of Florida. Moffat, Yard, and Company. DOI: 10.5479/sil.34513.39088015011976

Moses, W. R. (1947) The Journal of the Everglades Exploring Expedition: March 14 April 16,1892. In The Ingraham Everglades Exploring Expedition, 1892, edited by Watt P. Marchman. Tequesta VII (1947): 3-43.

Munroe, K. (1890). A Forgotten Remnant. Scribner's Magazine 8.

https://www.google.com/books/edition//KsACAAAAMAAJ.

Mulroy, K. (2003) Freedom on the Border: the Seminole Maroons in Florida, the Indian Territory, Coahuila, and Texas. Texas Tech University Press.

Nash, R. (1932) Survey of the Seminole Indians of Florida. Department of the Interior. https://ufdc.ufl.edu/FS00000029.

Ober, F. A. (1875a) Ten Days with the Seminoles, Part I. Appletons' Journal 14(332), 142-144.

https://quod.lib.umich.edu/m/moajrnl/acw843 3.1-14.332/146:4.

Ober, F. A. (1875b) Ten Days with the Seminoles, Part II. Appletons' Journal 14(333), 171-173.

https://quod.lib.umich.edu/m/moajrnl/acw843 3.1-14.333/175:4

Osceola, B. (1972, March 1) Interview with Billy Osceola [Interview]. Samuel Proctor Oral History Program, Seminole Oral History Collection, University of Florida. https://ufdc.ufl.edu/UF00007937.

Osceola, J. (n.d.) Interview with Joe Osceola. Samuel Proctor Oral History Program, Seminole Oral History Collection, University of Florida. https://ufdc.ufl.edu/UF00007905.

Peres, T. M. (2017) Foodways Archaeology: A Decade of Research from the Southeastern United States. Journal of Archaeological Research, 25, 421-460. DOI: 10.1007/s10814017-9104-4

Gonzalez, A.D. (2021) Seminole Food: Patterns of Indigenous Foodways in South Florida, 1855 to 1917. 
Raulerson, H. (1972, September 28) Interview with Hiram Raulerson [Interview]. Samuel Proctor Oral History Program, Seminole Oral History Collection, University of Florida. https://ufdc.ufl.edu/UF00007933.

Reno, J. W. (1971, October 21) Interview with Jane Wood Reno [Interview]. Samuel Proctor Oral History Program, Seminole Oral History Collection, University of Florida. https://ufdc.ufl.edu/UF00007911.

Roberts, W. (1973, April) Interview with William $D$. Roberts [Interview]. Samuel Proctor Oral History Program, Seminole Oral History Collection, University of Florida. https://ufdc.ufl.edu/UF00007958.

Sattler, R. A. (1996) Remnants, Renegades, and Runaways: Seminole Ethnogenesis Revisited. In J.D. Hill (Ed.), History, Power, and Identity: Ethnogenesis in the Americas. University of lowa Press. DOI: 10.1163/15691675_001_01-10

Shore, F. (1972a, October 1) Interview with Frank Shore [Interview]. Samuel Proctor Oral History Program, Seminole Oral History Collection, University of Florida. https://ufdc.ufl.edu/UF00007941.

Shore, F. (1972b, October 9) Interview with Frank Shore [Interview]. Samuel Proctor Oral History Program, Seminole Oral History Collection, University of Florida. https://ufdc.ufl.edu/UF00007948.

Skinner, A. (1913) Notes on the Florida Seminole. American Anthropologist 15(1), 63-77. DOI: 10.1525/aa.1913.15.1.02a00070

Sleight F.W. (1953) Kunti, a Food Staple of the Florida Indians. Florida Anthropologist, 6(2), 46-52. https://palmm. digital.flvc.org/islandora/object/uf\%3A32376.

St. Anthony. (1976, August 28) Interview with Sister St. Anthony [Interview]. Samuel Proctor Oral History Program, Seminole Oral History Collection, University of Florida. https://ufdc.ufl.edu/UF00008018.

Stephens, C. H. (1883) Isté Semoli. The Continent III, no. 10, March 7, 289-293.
Sturtevant, W. C. (1954) The Mikasuki Seminole: Medical Beliefs and Practices [Doctoral Dissertation]. Yale University.

Sturtevant, W. C. (1956) R.H. Pratt's Report on the Seminole in 1879. The Florida Anthropologist 9(1), March, 1-18. https://ufdc.ufl.edu/UF00027829/00121/1j.

Thompson, M. D. (1975, June 25) Interview with Milton D. Thompson. Samuel Proctor Oral History Program, Seminole Oral History Collection, University of Florida. https://ufdc.ufl.edu/UF00008008.

Tiger, B. (1998, August 27) Interview with Buffalo Tiger [Interview]. Samuel Proctor Oral History Program, Seminole Oral History Collection, University of Florida.https://ufdc.ufl.edu/UF00008078.

United States House of Representatives. (1917) Condition of the Florida Seminoles. In Condition of the Florida Seminoles: Hearings Before the Committee on Investigation of the Indian Service, 3. Government Printing Office, 1917. http://dpanther.fiu.edu/dpService/dpPurlService/purl/pu00120001/.

Unnamed Seminole Man. (n.d.) Interview with Unnamed Seminole Man. Samuel Proctor Oral History Program, Seminole Oral History Collection, University of Florida.

VanDerwarker A.M. and K.R. Detwiler. (2002) Gendered Practice in Cherokee Foodways: A Spatial Analysis of Plant Remains from the Coweeta Creek Site. Southeastern Archaeology, 21 (1), Summer, 21-28. https://www.jstor.org/stable/40713484.

Weik, T. M. (2009) The Role of Ethnogenesis and Organization in the Development of African-Native American Settlements: an African Seminole Model. International Journal of Historical Archaeology, 13(2), June, 206238. DOI: 10.1007/s10761-009-0079-9

Weisman B. R. (1989) Like Beads on a String: A Culture History of the Seminole Indians in North Peninsular Florida. University of Alabama Press.

Weisman, B. R. (2007) Nativism, Resistance, and Ethnogenesis of the Florida Seminole

Gonzalez, A.D. (2021) Seminole Food: Patterns of Indigenous Foodways in South Florida, 1855 to 1917. 
Indian Identity. Historical Archaeology.

41(4), 198-212. DOI: 10.1007/bf03377302

Weisman B. R. (2014) The Background and Continued Cultural and Historical Importance of the Seminole Wars in Florida.

FIU Law Review, 9(2), 391-404. DOI:

10.25148/lawrev.9.2.14

Willoughby, H. L. (1898) Across the Everglades: A Canoe Journey of Exploration. J.B. Lippincott Company.
Wilson, A.M. (1888) A.M. Wilson to J.D.C. Atkins, November 3, 1887. From Department of the Interior, Message from the President of the United States, transmitting a letter of the Secretary of the Interior relative to land upon which to locate Seminole Indians. https://digitalcommons.law.ou.edu/indianserialset/4308/.

\section{Appendix A: Historical Document Index}

\begin{tabular}{|c|c|c|c|c|}
\hline $\begin{array}{l}\text { Date } \\
\text { of } \\
\text { Visit }\end{array}$ & $\begin{array}{l}\text { Visitor's } \\
\text { Name }\end{array}$ & Visitor's Occupation & Purpose of Visit & $\begin{array}{c}\text { Associated } \\
\text { Citation }\end{array}$ \\
\hline
\end{tabular}

Canova describes his experiences during the Third

\begin{tabular}{|c|c|c|c|c|}
\hline & $\begin{array}{c}\text { Canova, An- } \\
\text { drew P. }\end{array}$ & $\begin{array}{r}\text { U.S. So } \\
\text { South Flo }\end{array}$ & $\begin{array}{l}\text { Seminole War and, later, as } \\
\text { a resident of South Florida. }\end{array}$ & $\begin{array}{c}\text { Canova, } \\
1855\end{array}$ \\
\hline & $\begin{array}{c}\text { Ober, Fred } \\
\text { (also pub- } \\
\text { lished as Fre } \\
\text { Beverly) }\end{array}$ & $\begin{array}{c}\text { Journalist and } \\
\text { ralist }\end{array}$ & $\begin{array}{c}\text { Production of a journalistic } \\
\text { account of Seminole life } \\
\text { based on observation and } \\
\text { testimony of other white ob- } \\
\text { servers. }\end{array}$ & $\begin{array}{l}\text { Ober 1875a, } \\
\text { 1875b; } \\
\text { Beverly, } \\
\text { 1876a, } \\
1876 b\end{array}$ \\
\hline
\end{tabular}

Sent on behalf of the Office of Indian Affairs to evaluate the possibility of removing remaining Seminoles to the Sturvtevant, West. 1956

\begin{tabular}{|c|c|c|c|c|}
\hline 1879 & Pratt, R.H. & Indian Agent & West. & 1956 \\
\hline 1881 & $\begin{array}{l}\text { MacCauley, } \\
\text { Clay. }\end{array}$ & $\begin{array}{l}\text { Ethnologist, Smith- } \\
\text { sonian }\end{array}$ & $\begin{array}{l}\text { Sent on field assignment by } \\
\text { the Smithsonian for purpose } \\
\text { of data collection. }\end{array}$ & $\begin{array}{c}\text { MacCauley, } \\
1887\end{array}$ \\
\hline 1883 & $\begin{array}{l}\text { Stephens, } \\
\text { Charles H. }\end{array}$ & $\begin{array}{c}\text { Illustrator and artifact } \\
\text { collector }\end{array}$ & $\begin{array}{l}\text { Production of a journalistic } \\
\text { account of Seminole life. } \\
\text { Possibly also an artifact-col- } \\
\text { lection trip. }\end{array}$ & $\begin{array}{c}\text { Stephens, } \\
1883 \\
\end{array}$ \\
\hline
\end{tabular}

1888 Wilson, A.M. Indian Agent

Charged with evaluating the Seminole situation in South Florida for purposes of reservation planning.

Wilson, 1888 


\begin{tabular}{|c|c|c|c|c|}
\hline $\begin{array}{l}\text { Date } \\
\text { of } \\
\text { Visit }\end{array}$ & $\begin{array}{l}\text { Visitor's } \\
\text { Name }\end{array}$ & Visitor's Occupation & Purpose of Visit & $\begin{array}{l}\text { Associated } \\
\text { Citation }\end{array}$ \\
\hline 1889 & $\begin{array}{l}\text { Unknown Vis- } \\
\text { itor }\end{array}$ & Unknown Visitor & $\begin{array}{l}\text { Purpose unknown, cited by } \\
\text { Covington as printed by Fort } \\
\text { Myers Press in } 1889 .\end{array}$ & $\begin{array}{c}\text { Covington, } \\
1974 \\
\end{array}$ \\
\hline 1890 & Munroe, Kirk & $\begin{array}{c}\text { Journalist, explorer, } \\
\text { and author }\end{array}$ & $\begin{array}{l}\text { Production of a journalistic } \\
\text { account of Seminole life. } \\
\text { May have been a regular } \\
\text { guest in Seminole homes. }\end{array}$ & $\begin{array}{c}\text { Munroe, } \\
1890 \\
\end{array}$ \\
\hline 1893 & Brecht, J.E. & Indian Agent & $\begin{array}{c}\text { Evaluation of Seminole liv- } \\
\text { ing conditions in an effort to } \\
\text { establish an industrial-medi- } \\
\text { cal station in the vicinity of } \\
\text { Big Cypress. }\end{array}$ & $\begin{array}{c}\text { Brecht, } \\
1893\end{array}$ \\
\hline 1893 & $\begin{array}{l}\text { Ingraham, } \\
\text { James E. }\end{array}$ & $\begin{array}{l}\text { President of the } \\
\text { South Florida Rail- } \\
\text { road Company } \\
\text { (SFRC) }\end{array}$ & $\begin{array}{l}\text { General reconnaisance re- } \\
\text { port for the chair of the } \\
\text { SFRC's parent corporation, } \\
\text { the Plant Company. }\end{array}$ & $\begin{array}{c}\text { Moses, } \\
1947\end{array}$ \\
\hline 1896 & $\begin{array}{c}\text { Cory, Charles } \\
\text { B. }\end{array}$ & Ornithologist & $\begin{array}{l}\text { Ornithological and ethno- } \\
\text { graphic research and hunt- } \\
\text { ing-ground reconnaisance. }\end{array}$ & Cory, 1896 \\
\hline 1896 & $\begin{array}{l}\text { Moore-Wil- } \\
\text { son, Minnie }\end{array}$ & $\begin{array}{c}\text { Author and local ac- } \\
\text { tivist }\end{array}$ & $\begin{array}{c}\text { Activist and author describ- } \\
\text { ing Seminole life for poster- } \\
\text { ity and arguing for the es- } \\
\text { tablishment of a Seminole } \\
\text { reservation. }\end{array}$ & $\begin{array}{c}\text { Moore-Wil- } \\
\text { son, 1914 } \\
{[1896]} \\
\end{array}$ \\
\hline 1898 & $\begin{array}{l}\text { Willoughby, } \\
\text { Hugh L. }\end{array}$ & $\begin{array}{l}\text { Former Navy lieuten- } \\
\text { ant and naturalist }\end{array}$ & $\begin{array}{c}\text { Production of a descriptive } \\
\text { account of Everglades flora } \\
\text { and fauna. }\end{array}$ & $\begin{array}{c}\text { Willoughby } \\
1898\end{array}$ \\
\hline 1898 & Duncan, A.J. & Indian Inspector & $\begin{array}{l}\text { Reporting to the Secretary } \\
\text { of the Interior on Seminoles } \\
\text { living conditions and geog- } \\
\text { raphy, offering suggestions } \\
\text { as to potential reservation } \\
\text { locations. }\end{array}$ & $\begin{array}{c}\text { Duncan, } \\
1898 \\
\end{array}$ \\
\hline
\end{tabular}

Genral description of Seminole life designed to illus-

Trout, Irenaeus,

(In Covington Episcopalian Mission1908 1973) ary trate the need for a civilizing and Christianizing mission, justifying expenditures and requesting more funds.

Covington, 1973 


\begin{tabular}{|c|c|c|c|c|}
\hline $\begin{array}{l}\text { Date } \\
\text { of } \\
\text { Visit }\end{array}$ & $\begin{array}{l}\text { Visitor's } \\
\text { Name }\end{array}$ & Visitor's Occupation & Purpose of Visit & $\begin{array}{l}\text { Associated } \\
\text { Citation }\end{array}$ \\
\hline 1910 & $\begin{array}{l}\text { Skinner, Alan- } \\
\text { son }\end{array}$ & $\begin{array}{l}\text { Ethnologist, American } \\
\text { Museum of Natural } \\
\text { History (AMNH) }\end{array}$ & $\begin{array}{l}\text { Specimen collection for } \\
\text { AMNH. }\end{array}$ & $\begin{array}{c}\text { Skinner, } \\
1910\end{array}$ \\
\hline 1917 & $\begin{array}{l}\text { U.S. House of } \\
\text { Representa- } \\
\text { tives }\end{array}$ & $\mathrm{N} / \mathrm{A}$ & $\begin{array}{l}\text { Visit of U.S. House commit- } \\
\text { tee to South Florida to eval- } \\
\text { uate the condition of the } \\
\text { Seminole Indians. }\end{array}$ & $\begin{array}{l}\text { U.S. House } \\
1917\end{array}$ \\
\hline
\end{tabular}

\section{Appendix B: Index of Species Referenced in Text}

Wild Foods and Origin Species

\begin{tabular}{|c|c|c|}
\hline \multirow{11}{*}{  } & Food Common Name & Food Source Specific Name \\
\hline & $\begin{array}{l}\text { White Tailed Deer (Veni- } \\
\text { son) }\end{array}$ & Odocoileus virginianus \\
\hline & Turkey & Meleagris gallopavo \\
\hline & Bear & Ursus americanus \\
\hline & Duck & Anas platyrhynchos \\
\hline & Opossum & Genus Didelphis \\
\hline & Quail & Colinus virginianus \\
\hline & Rabbit & Genus Oryctolagus \\
\hline & Squirrel & Genus Sciurus \\
\hline & Wild Birds & Unknown \\
\hline & Wild Bird Egg & Unknown \\
\hline \multirow{7}{*}{ 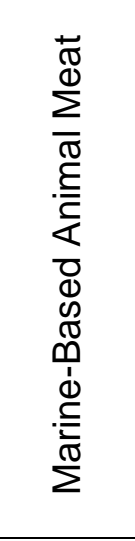 } & Alligator & Alligator mississippiensis \\
\hline & Fish (general) & Unknown \\
\hline & Turtle or Tortoise & $\begin{array}{l}\text { Malaclemys terrapin or } \\
\text { Gopherus polyphemus }\end{array}$ \\
\hline & Black bass & Micropterus Floridanus \\
\hline & Oysters & Crassostrea virginica \\
\hline & Trout & $\begin{array}{c}\text { Presumably Cynoscion arenar- } \\
\text { ius }\end{array}$ \\
\hline & Manatee & Trichechus manatus latirostris \\
\hline \multirow{4}{*}{ 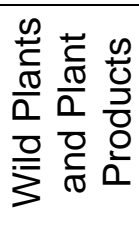 } & Coontie & Zamia pumila \\
\hline & Cabbage Palm & Sabal palmetto \\
\hline & Honey & $\mathrm{N} / \mathrm{A}$ \\
\hline & Wild potato & Unknown \\
\hline
\end{tabular}

Gonzalez, A.D. (2021) Seminole Food: Patterns of Indigenous Foodways in South Florida, 1855 to 1917. New Florida Journal of Anthropology 1(2),47-71 DOI 10.32473/nfja.v112.123723 


\begin{tabular}{|c|c|c|}
\hline \multirow{5}{*}{ 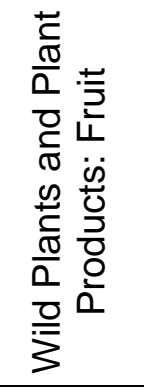 } & Cocoplum & Chysobalnus icaco \\
\hline & Myrtle berries & Myrica cerifera \\
\hline & Pigeon plum & Coccoloba diversifolia \\
\hline & Saffron plum & Sideroxylon celastrinum \\
\hline & Seagrape & Coccoloba uvifera \\
\hline \multirow{2}{*}{ 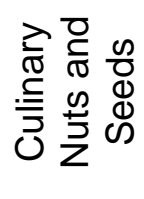 } & Cacao nut & Theobroma cacao \\
\hline & Peanut & Arachis hypogaea \\
\hline
\end{tabular}

Foods of Domesticated Origin

\begin{tabular}{|c|c|c|}
\hline & Food Common Name & Food Source Specific Name \\
\hline \multirow{8}{*}{  } & Corn & Zea mays \\
\hline & Sugar cane & Saccharum officinarum \\
\hline & Pumpkin & Cucurbita moschata \\
\hline & Rice & Oryza sativa \\
\hline & $\begin{array}{l}\text { Sweet } \\
\text { Potato }\end{array}$ & Ipomoea batatas \\
\hline & Squash (non-pumpkin) & Genus Cucurbita \\
\hline & Beans (general) & Presumably genus Phasoleus \\
\hline & Lima Beans & Phaseolus lunatus \\
\hline \multirow{8}{*}{ 䟫 } & Banana & $\begin{array}{c}\text { At least Musa paradisiaca anc } \\
\text { Musa acuminata }\end{array}$ \\
\hline & Melon (general) & Presumably Cucumis melo \\
\hline & Lemon & Citrus limon \\
\hline & Orange & Citrus sinensis \\
\hline & Guava & Psidium guajava \\
\hline & Lime & Citrus aurantiifolia \\
\hline & Pineapple & Ananas comosus \\
\hline & Grapes & Genus Vitis \\
\hline \multirow{4}{*}{ 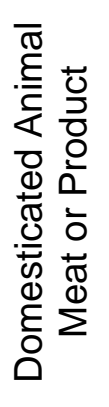 } & Pig (Pork) & Sus scrofa \\
\hline & Chicken & Gallus gallus \\
\hline & Cattle (Beef) & Bos taurus \\
\hline & Chicken egg & Gallus gallus \\
\hline
\end{tabular}

Gonzalez, A.D. (2021) Seminole Food: Patterns of Indigenous Foodways in South Florida, 1855 to 1917. New Florida Journal of Anthropology 1(2),47-71 DOI 10.32473/nfja.v112.123723 